\title{
JÄNNITTÄMINEN JA OPISKELUKYKY
}

\section{Merja Almonkari}

Lection praecursoria puheviestinnän väitöskirjan "Jännittäminen opiskelun puheviestintätilanteissa" tarkastustilaisuudessa Jyväskylän yliopistossa 21.12.2007. Vastaväittäjänä tilaisuudessa oli KT Leena Penttinen (Joensuun yliopisto) ja kustoksena professori Maarit Valo.

Oppiminen on opiskelijan työtä. Työnä oppiminen on vaativaa ja edellyttää hyvää työkykyä, josta käytetään opiskelun yhteydessä termiä opiskelukyky. Opiskelukykyyn vaikuttavat monet tekijät. Osa näistä liittyy opiskelijaan itseensä, osa opiskeluympäristöön. Opiskelijaan liittyviä tekijöitä ovat esimerkiksi hänen persoonallisuutensa ja elämäntilanteensa, hänen terveytensä ja voimavaransa. Tärkeitä opiskelukyvyn osatekijöitä ovat opiskelutaidot, opintosuunnitelman tekeminen, ajankäytön suunnittelu ja yleinen suhtautuminen opiskeluun. Lisäksi monet opiskeluympäristön tekijät, opiskelun olosuhteet ja ulkoiset puitteet vaikuttavat opiskelijan kykyyn opiskella. Yliopiston henkilökunnan ja opiskelijoiden välinen vuorovaikutus, opiskeluilmapiiri sekä opiskelijoiden keskinäinen kanssakäyminen ovat myös osa opiskeluympäristöä. Opetus ja ohjaus ovat merkittäviä opiskelukykyä rakentavia tekijöitä. Tähän kuuluvat esimerkiksi opetushenkilökunnan pedagoginen osaaminen, tuutorointi, opinnäytetöiden ohjaus, arviointi ja palautteen antaminen sekä opiskelijan integroituminen opiskeluyhteisöönsä. Opiskelukyky määrittyy siis monelta osin vuorovaikutustilanteissa.

Olen tarkastellut väitöstutkimuksessani ilmiötä, jolla on monta nimeä: sosiaalinen jännittäminen, viestintäarkuus, ujous, sosiaalis- 
ten tilanteiden pelko ja vähäpuheisuus. Opiskelijan toiminta opiskelun viestintätilanteissa ja hänen vuorovaikutuskokemuksensa ovat osa opiskelukykyä. Jännittäminen tai jopa pelkääminen sosiaalisissa tilanteissa on monille opiskelijoille suuri haaste, joillekin myös todellinen ongelma, opiskelukykyisyyden uhka ja pahoinvointia tuottava tekijä. Halusin tutkimuksessani selvittää, millaisesta ilmiöstä jännittämisessä yliopisto-opiskelussa on kysymys, miten paljon sitä koetaan ja miten sen kanssa tullaan toimeen.

Hankin tutkimusaineistoni vuonna 2005 internetkyselyn avulla. Kyselyni vastaajat olivat Jyväskylän yliopiston kolmannen, neljännen ja viidennen vuoden opiskelijoita, ja he edustivat tasaisesti yliopiston eri tiedekuntia. Lisäaineistona olen käyttänyt vuonna 2004 kerättyä valtakunnallisen opiskelijoiden terveystutkimuksen aineistoa. Siihen oli kerätty postikyselyn avulla laajasti tietoa yliopisto-opiskelijoiden fyysiseen, psyykkiseen ja sosiaaliseen terveyteen liittyvistä seikoista kaikista Suomen yliopistoista ja kaikilta opintoaloilta. Opiskelijoiden vastauksia on käsitelty sekä tilastollisin menetelmin että vastausten sisältöjä analysoiden ja tulkiten. Tutkimukseni tulokset perustuvat opiskelijoiden itse omasta jännittämisestään antamiin arviointeihin ja kuvailuihin. Aineistot sisälsivät yhteensä 4400 opiskelijan vastaukset.

Missä opiskelun tilanteissa opiskelijat kokevat sosiaalista jännittämistä? Seminaariesitelmän pitäminen, vieraan kielen puhuminen kurssilla, luennolla kysyminen ja vastaaminen, opponenttina toimiminen seminaarissa sekä osallistuminen kurssille, jossa harjoitellaan puheviestinnän taitoja, ovat niitä tilanteita, joissa yliopisto-opiskelijat arvioivat toistuvimmin ja intensiivisimmin jännittävänsä. Vastauksissa kuvattiin myös tentteihin, testeihin, pääsykokeisiin ja oppimistehtävien esittelyyn liittyneitä jännittämisen kokemuksia.

Ahdistuneisuutta, pelkoa, hermostuneisuutta ja muita sosiaalisen jännittämisen piirteitä koettiin eniten tilanteissa, joita yhdisti runsas esilläolo, huomion kohdistuminen puhujaan, kognitiivisesti kuormittavat 
viestinnän sisällöt ja opiskelijalle uusi rooli. Huomattava tilannepiirre oli myös tilanteen harvinaisuus tai uutuus. Seminaariesitelmiä ja opponointeja sisältynee yhden opiskelijan opintoihin vain kahdesta kuuteen kappaletta, kieli- ja viestintäkurssejakin vain muutamia.

Tilanteiden kokeminen ei ollut yhdenmukaista, vaan siinä esiintyi suurta vaihtelua. Oli niitä, jotka eivät jännittäneet lainkaan, ja toisaalta niitä, jotka jännittivät aina. Oli myös tilanteita, joissa koettiin hyvin harvoin jännittämistä. Näitä olivat tilanteet, joissa opiskelijalla oli hyvin passiivinen rooli, kuten luentoa kuunnellessa, tai neutraali asiointifunktio viestinnässä, kuten kirjastovirkailijan kanssa puhuessa. Jännittämistä koettiin myös hyvin harvoin sosiaaliseen rupatteluun painottuvissa tilanteissa, kuten juteltaessa luentotauolla kurssikavereiden kanssa.

Opiskelijoiden jännittäminen oli hyvin usein luonteeltaan ennakkojännittämistä. Fyysisiä tuntemuksia, hermostumista ja ahdistumista alettiin kokea ennen tilannetta. Joillakin tämä alkoi jo useita päiviä ennen tärkeää opiskeluun liittyvää puhetehtävää, jotkut kertoivat alkavansa jännittää edellisenä iltana tai vasta ennen tilanteen alkamista. Ennakkojännittämisessä mielikuvat tulevasta tilanteesta ovat keskeisessä asemassa.

Merkille pantavaa on, että jännittäminen opiskelutilanteessa ei välttämättä tarkoittanut haitallista, toimintaa estävää tai vaikeuksia tuovaa jännittämistä. Erityisesti tämä tuli esille esiintymisviestinnän kohdalla: ongelmia esiintymisessä koki noin kolmasosa, kun taas neljäsosan mielestä esiintyminen ei anna aihetta erityiseen huomioon, vaan on tavanomainen osa opiskelua. Lähes puolet yliopisto-opiskelijoista koki esiintymisen myönteisenä. Heistä neljännes raportoi kuitenkin jännittävänsä esiintymistilanteissa toistuvasti. Tämän perusteella voi todeta, että opiskelijat osaavat tulkita jännittämisensä myös myönteisesti.

Miten opiskelijat sitten tulevat toimeen jännittämisensä kanssa? Yliopisto-opiskelijat kuvailivat varsin monenlaisia stressaaviin opiskelutilanteisiin helpotusta tuovia toimintatapoja. Monien mie- 
lestä valmistautumisen määrä vaikutti ratkaisevasti jännittämisen määrään: mitä enemmän valmistelee ja harjoittelee, sitä vähemmän jännittää. Hyvin suosittuja olivat mentaaliset, mielen hallintaan liittyvät selviytymiskeinot. Opiskelijat toistelivat mielessään esimerkiksi lauseita Olen selviytynyt aina ennenkin, Olen valmistautunut hyvin ja osaan asiani, Jännittäminen on normaalia, Esitelmänpitoon ei kuole tai Me kaikki olemme vain ihmisiä. Tällaisten asioiden suhteellisuutta, viestintäkumppaneiden tasa-arvoisuutta ja itsen kannustusta korostavien ajatusten avulla opiskelijat kokivat rauhoittuvansa ja keskittyvänsä. Muut selviytymiskeinot perustuivat tuen saamiseen ystäviltä tai jumalalta, rentouden hakemiseen liikunnasta ja hengitysharjoituksista, varmuuden hakemiseen viimeistellystä ulkonäöstä, huumorin voimaan tai syömisen ja juomisen avulla haettuun mielihyvään.

Opiskelijat kokivat selviytyvänsä jännittämisensä kanssa keskimäärin hyvin. Vaikka jännittämiselle annettiin paljon kielteisiä tulkintoja ja monet pitivät sitä omana heikkoutenaan, sen kanssa osattiin elää ja opiskella. Kolme neljäsosaa oli sitä mieltä, että opiskelun puheviestintätilanteissa koettu jännittäminen ei ole vaikuttanut opintojen etenemiseen tai tutkinnon valmistumiseen mitenkään. Ne opiskelijat, joiden mielestä jännittäminen vaikuttaa opintojen etenemiseen, kertoivat sen vaikuttavan kurssivalintoihin ja kurssien ajoitukseen sekä lisäävän henkistä kuormittumista. Kieli- ja viestintäopintojen kurssit, kaikki seminaarit sekä omien tuotosten esittelyä sisältävät kurssit ovat suuria haasteita niille opiskelijoille, jotka kokevat toistuvaa sosiaalista jännittämistä. Niitä lykätään ja vältellään mielellään. Näille opiskelijoille sosiaalinen jännittäminen on opiskelukyvyn uhkatekijä.

Jännittämisen kokemisessa havaitut erot liittyivät opiskelijan sukupuoleen, opintosuoritusten määrään, opintoalaan, opiskelun kokemiseen, viestijäkuvaan, kontakteihin, terveydentilaan, aikaisempiin vuorovaikutuskokemuksiin sekä jännittämisen arvioituihin syihin. Naisopiskelijat arvioivat kokevansa sosiaalista jännittämistä opiskelutilanteissa toistuvammin kuin miehet, mutta erot 
eivät olleet suuria. Useimmin jännittämistä kokivat informaatioteknologian, matemaattis-luonnontieteellisen ja yhteiskuntatieteellisen tiedekunnan opiskelijat.

Jännittämistä on aikaisemmissa tutkimuksissa tarkasteltu erillään selviytymiskeinoista ja yksilön kokemista voimavaroista. Tässä tutkimuksessa otettiin huomioon myös selviytymiskeinojen repertuaari. Tämä monimuotoisti opiskelijoiden sosiaalisesta jännittämisestä syntyvää kuvaa entisestään. Tilastollisten analyysien avulla aineistosta muodostettiin ryhmiä, joihin luokitellut opiskelijat olivat sosiaalisen jännittämisen ominaisuuksiltaan samantyyppisiä. Tulokseksi saatiin viisi ryhmää eli viisi "jännittämisen tyyppiä" tai "jännittämisprofiilia".

Vahvasti viestintäarkojen ryhmään luokiteltuja yhdisti toistuva jännittäminen lähes kaikissa opiskelun puheviestintätilanteissa, kielteinen viestijäkuva ja vähäiset selviytymiskeinot. Ryhmään luokittui $4 \%$ opiskelijoista.

Viestintähaluttomien ryhmään luokiteltujen opiskelijoiden piirteet viittasivat ujouteen, vähäpuheisuuteen ja viestintähaluttomuuteen. Ryhmä sai nimensä tilanteiden välttelytaipumuksen ja kielteisten vuorovaikutusasenteiden perusteella. Ryhmään kuului $16 \%$ opiskelijoista.

Kolmannen ryhmän, esiintymisjännittäjät, muodostivat opiskelijat, joille oli tyypillistä toistuva ja voimakas esiintymistilanteissa jännittäminen mutta toisaalta myönteinen viestijäkuva, myönteiset asenteet vuorovaikutusta kohtaan ja luja usko omaan selviytymiseen. Tässä ryhmässä runsas esiintymisjännitys yhdistyi monipuolisiin selviytymiskeinoihin, joita sävyttivät myönteiset ajatukset ja läheisiltä haettu sosiaalinen tuki. Opiskelijoista $25 \%$ luokiteltiin tähän ryhmään.

Neljäs ryhmä sai nimekseen viestintähuolettomat, koska vaikka ryhmäläiset jännittivät silloin tällöin joissakin opiskelutilanteissa, 
he eivät tehneet jännittämisestään itselleen eivätkä muille mitään suurta numeroa. "Ei kannata turhaan stressata" kuvasi hyvin heidän huoletonta asennettaan. Ryhmään kuului $26 \%$ vastaajista.

Viides ryhmä, viestintävarmat, koostui opiskelijoista, joille sosiaalinen jännittäminen oli harvinainen tai kokonaan tuntematon kokemus. Heitä yhdisti selkeän myönteinen viestijäkuva ja vahva itseluottamus. Opiskelijoista $22 \%$ kuului tähän ryhmään.

Pelkästään jännittämisen ilmenemismuotojen perusteella ei voi päätellä jännittämisen vaikutusta opiskelijan elämään. "Oireet" eivät toisin sanoen kerro "haitta-asteesta". Jännittämisen tarkastelussa olisikin kiinnitettävä enemmän huomiota haittaavaksi koettua jännittämistä helpottaviin suhtautumistapoihin ja selviytymiskeinoihin. Runsaaseen jännittämiseen voi liittyä yhtä lailla apaattinen kärsiminen, eristäytyminen ja selviytymiskeinojen puute kuin myönteiset vuorovaikutusasenteet ja selviytymiskeinojen laaja ja monipuolinen valikoima.

Yksilötasolla suurin haaste jännittämisen ymmärtämisessä on sen hyväksyminen itsessään. Monet opiskelijat haluaisivat, että koko ilmiötä ei olisi olemassa. He kokevat sen esteenä ja haittana kanssakäymiselle muiden ihmisten kanssa. "Ilman jännittämistä elämä olisi paljon helpompaa", kirjoitti eräs opiskelija.

Nykypäivänä hyvänä esiintyjänä pidetään sellaista, joka ilmentää myönteisyyttä, varmuutta, vahvaa tahtoa ja kontaktihalukkuutta yleisön kanssa. Yleisölle tai asiakkaalle pitäisi syntyä vaikutelma vakuuttavasta viestijästä. Puhuja kokee itsensä helposti riittämättömäksi, kun ei löydä itsestään sitä varmuutta, jota kuvittelee kuuntelijoidensa ja keskustelukumppaneidensa vaativan ja odottavan. On harmillista ja oikeastaan suuri vahinko, että epävarmuuden, hermostumisen ja jännittyneisyyden kokemus niputetaan yhteen osaamattomuuden ja taidottomuuden kanssa. Ihminenhän voi olla vakuuttava ja varma viestijä, vaikka hän kokee epävarmuutta ja jännittää. Viestintätaidot ja asian hallinta ovat eri asia kuin jännit- 
tämiseen liittyvät kehon tuntemukset tai mielessä syntyvät ahdistavat ajatukset ja epävarma olotila. Tietty tunnetila tai kokemisen tapa ei myöskään poista ihmisestä hänen ammatillista osaamistaan. Sekä jännityksensä heikkoutena kokeva että jännitystä toisessa kriittisesti havainnoiva tarvitsivat molemmat sallivuutta ja suvaitsevuutta. Tunteiden tunteminen kuuluu kanssakäymiseen. Tunnetaidot, kuten omien tunteiden tunnistaminen ja kohtaaminen, ovat tärkeä osa opiskelutaitoja.

Tutkimuksessani selvisi, että opiskelutilanteissa on paljon jännittämistä ja että se tihentyy tietyntyyppisiin tilanteisiin. Haittaavasta jännittämisestä kärsii noin viiden prosentin suuruinen vähemmistö opiskelijoista. Nykyaikana jännittäminen nähdään yksilön ongelmana ja niinpä ajatellaan, että juuri tämä vähemmistö kaipaa erityistä tukea. Ongelman ydin voidaan sijoittaa myös opiskeluympäristöön ja yliopiston rakenteisiin. Otan esimerkin historiasta. Yli sata vuotta sitten, vuonna 1870 , kouluylihallitus varoitti Jyväskylän seminaarin opettajia rasittamasta liikaa opiskelijoita ja tiedusteli, oliko seminaarissa "jokin haitallinen opinnoimistapa päässyt muodostumaan". Esitettiin arvio, että "oppijoita jännitettiin liikaa ja siirryttiin tavan takaa asiasta ja oppiaineesta toiseen". Opiskelun tuntimääriä olikin opiskelijoiden liikarasituksen vuoksi supistettava, kertoo Aimo Halila Jyväskylän seminaarin historiassa. Asia ymmärrettiin siis niin, että seminaari jännitti opiskelijoita ja ikään kuin venytti heidän opiskelukykyään liikaa. Opiskelijoiden työtaakkaan ja opiskeluympäristöön vaikuttamalla pyrittiin lisäämään opiskelijoiden hyvinvointia.

Jännittämiseen on onneksi nykypäivänäkin tarjolla monenlaista apua ja tukea, joskin opiskeluympäristöön olisi kiinnitettävä enemmän huomiota ja tukea antavien tahojen välille tarvittaisiin lisää yhteistyötä. Yliopistoissa on tehostettu opintojen ohjausta ja pyritty opiskelun esteettömyyteen. Jotkut kielikeskukset tarjoavat puheviestinnän kursseja, joilla voi harjoitella haastavissa tilanteissa tarvittavia viestintätaitoja ja saada tietoa jännittämisilmiöstä. Ylioppilaiden terveydenhoitosäätiö tarjoaa paitsi lääkehoitoa 
myös ohjattua vertaisryhmätoimintaa ja yksilöterapiaa haittaavasta jännittämisestä kärsiville. Ongelma on kuitenkin usein tuen tarvitsijan ja tarjoajan kohtaamattomuus. Opiskelija kärsii yksin eikä hakeudu tai pääse jonojen vuoksi avun äärelle. Jännittämisen kokemisessa on myös paljon yksilöllisiä eroja. Joku saa lievitystä jännittämiseensä esiintymisharjoittelusta, toinen selviytymiskeinojen opiskelusta, kolmas terapiasta ja lääkkeistä. Jonkun ahdistus vähenee jo turvalliseksi koetussa opiskeluilmapiirissä ja kanssakäymisessä opiskelijoista huolehtivan ja välittävän opettajan tai opinto-ohjaajan kanssa. Tutkimustulosteni perusteella olen esittänyt työssäni useita suosituksia siitä, miten jännittämisilmiö pitäisi ottaa huomioon niin opetuksen kuin terveydenhuollonkin alueella. Tärkeitä kehittämiskohteita ovat jännittämisen tunnistaminen ja sopivien tukimuotojen tarjoaminen, yhteisöllisyyttä ja ryhmäytymistä korostavat opetuskäytännöt sekä opiskelijoista huolehtiminen.

Kolme neljäsosaa opiskelijoista arvioi, että jännittäminen ei mitenkään ole vaikuttanut heidän opintojensa etenemiseen. Heidän raportoimiensa jännittämiskokemusten perusteella minulle tutkijana on hahmottunut myös toisenlainen kuva. Jännittäminen ei ehkä vaikuta yksilötasolla, mutta laajemmin se kyllä vaikuttaa. Ahdistuneisuus voi tietysti saada aikaan hyviä opintosuorituksia piiskaamalla opiskelijoita eteenpäin. Opiskelijoiden runsas ahdistuneisuus ja jännittyneisyys vaikuttaa kuitenkin kielteisesti opiskelutilanteiden vuorovaikutukseen ja oppimisprosessiin. Itseensä, omiin huoliinsa ja jännittämiseensä uppoutunut opiskelija ei ole kovin vastaanottavainen opetukselle eikä pysty antautumaan keskusteluihin muiden oppijoiden kanssa. Hänen tarkkaavaisuutensa fokus on oman turvallisuuden tai hyväksytyksi tulemisen huolehtimisessa, ei tieteeseen tutustumisessa tai muissa opittavissa asioissa. Mitä enemmän voidaan pedagogisilla keinoilla synnyttää onnistumisen kokemuksia, luoda turvallisuutta ja myönteisiä vuorovaikutuskokemuksia opiskelutilanteisiin, sitä paremmin myös edistetään oppimista ja opiskelijoiden kehittymistä oman alansa akateemisiksi asiantuntijoiksi. 
Ihminen oppii kokemuksistaan. Mitä eväitä yliopiston puheviestintäkokemukset tarjoavat akateemisille asiantuntijoille tulevaisuuden työelämään? Korostuuko viestinnässä yksilökeskeinen suoritushenki ja arvioitavana oleminen vai opitaanko enemmänkin heittäytymään dialogin pyörteisiin ja arvostamaan sekä omaa että toisen ajattelun erityislaatua? Osataanko olla kokeilunhaluisia, epävarmoja ja luovia ilman pelkoa nolatuksi tulemisesta tai naurunalaiseksi joutumisesta? Onnistumisen kokemukset ja hyvä ilmapiiri seminaareissa liitettynä pohdiskelevaan ja argumentoivaan keskusteluun tarjoaisi hienon mallin tulevaan asiantuntijatyöhön. Toivoisinkin, että kun opiskelijat poistuvat seminaareista posket hehkuen, tämä hehku olisi seurausta oppimisen ja oivaltamisen innosta, ei häpeästä ja hämillisyydestä. On sääli ja suuri menetys yliopistolle ja yhteiskunnalle, jos osa opiskelijoiden lahjakkuudesta ja innovatiivisuudesta jää tulematta esiin jännittämisen vuoksi. 